Prepared in cooperation with the Village of Delhi, New York; the Delaware County Soil and Water Conservation District; and the Delaware County Planning Department

\title{
Flood-Inundation Maps for the West Branch Delaware River, Delhi, New York, 2012
}

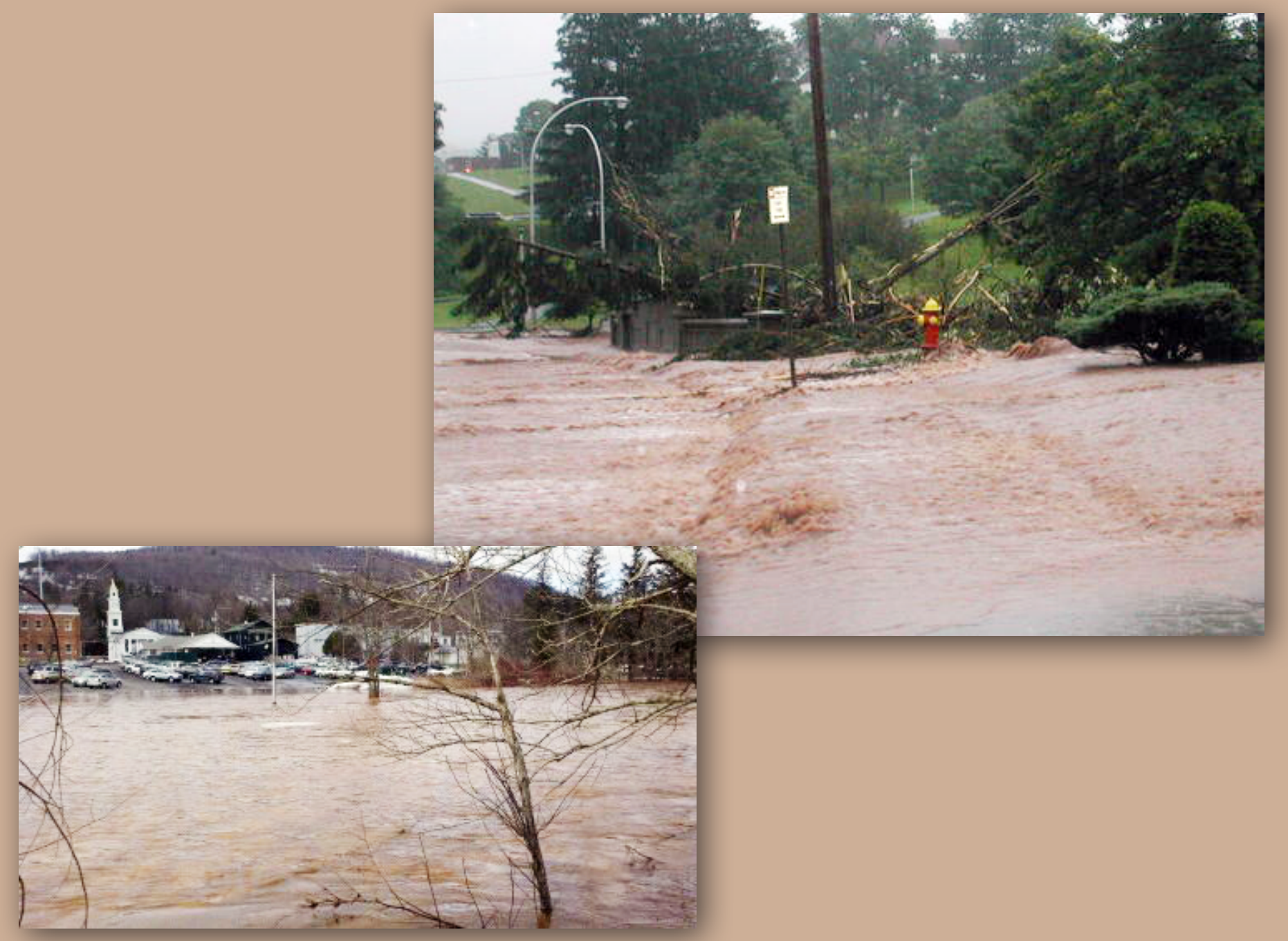

Pamphlet to accompany

Scientific Investigations Map 3216

U.S. Department of the Interior

U.S. Geological Survey 
Cover. Photographs of Delhi, New York, showing flooding along the main stem of the West Branch Delaware River and road overflow from a tributary, Steele Brook (photos by Graydon Dutcher, Delaware County Soil and Water Conservation District). 


\section{Flood-Inundation Maps for the West Branch Delaware River, Delhi, New York, 2012}

By William F. Coon and Brian K. Breaker

Prepared in cooperation with the Village of Delhi, New York; the Delaware County Soil and Water Conservation District; and the Delaware County Planning Department

Pamphlet to accompany

Scientific Investigations Map 3216 


\title{
U.S. Department of the Interior \\ KEN SALAZAR, Secretary \\ U.S. Geological Survey \\ Marcia K. McNutt, Director
}

\author{
U.S. Geological Survey, Reston, Virginia: 2012
}

For more information on the USGS - the Federal source for science about the Earth, its natural and living resources, natural hazards, and the environment, visit http://www.usgs.gov or call 1-888-ASK-USGS.

For an overview of USGS information products, including maps, imagery, and publications, visit http://www.usgs.gov/pubprod

To order this and other USGS information products, visit http://store.usgs.gov

Any use of trade, product, or firm names is for descriptive purposes only and does not imply endorsement by the U.S. Government.

Although this report is in the public domain, permission must be secured from the individual copyright owners to reproduce any copyrighted materials contained within this report.

Suggested citation:

Coon, W.F., and Breaker, B.K., 2012, Flood-inundation maps for the West Branch Delaware River, Delhi, New York, 2012: U.S. Geological Survey Scientific Investigations Map 3216, 9 p. pamphlet, 10 sheets, scale 1:20,000.

Available online at $h t t p: / / p u b s . u s g s . g o v / \operatorname{sim} / 3216$. 


\section{Acknowledgments}

The authors wish to thank the New York City Department of Environmental Protection and the Delaware County Department of Public Works for funding the operation and maintenance of the Delhi streamgage, data from which were used for this study. Special thanks are given to Michael Jastremski and Shelly Johnson of the Delaware County Planning Department for promoting communication among the local government agencies and to Graydon Dutcher of the Delaware County Soil and Water Conservation District for facilitating the application process by the Village of Delhi for funding of this study through the Stream Corridor Management Program. Thanks also go to Richard Maxey, the Mayor of Delhi, and to the Village Board, the lead agency in securing funding for this study. Finally, thanks go to the National Weather Service for continued support of the USGS flood-inundation mapping initiative. 


\section{Contents}

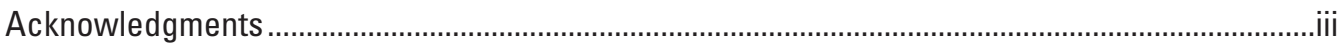

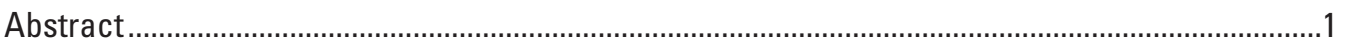

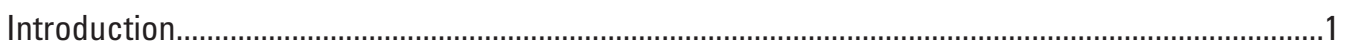

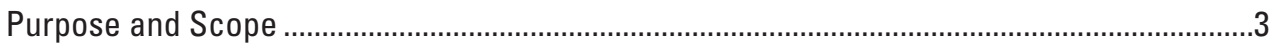

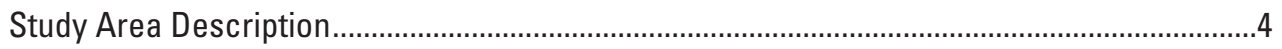

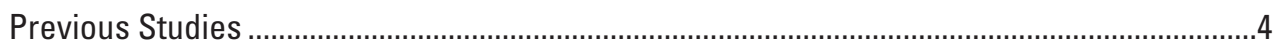

Approach .

Computation of Water-Surface Profiles................................................................................

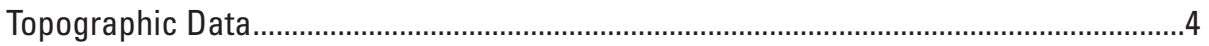

Hydrologic and Steady-State Flow Data........................................................................

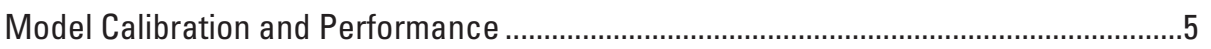

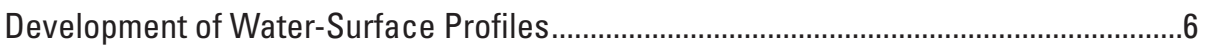

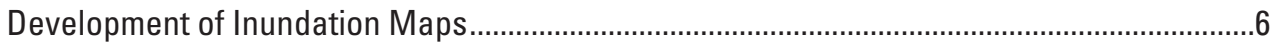

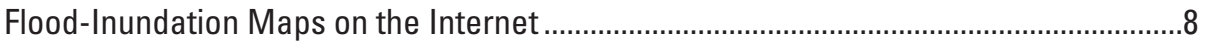

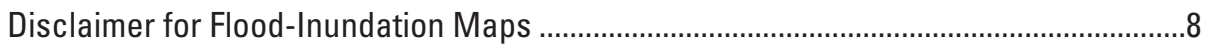

Uncertainty Associated with Inundation Maps ...........................................................

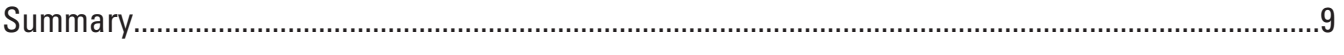

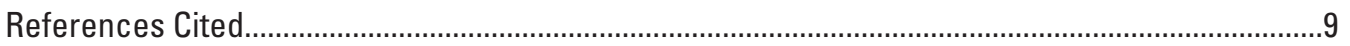

\section{Figures}

1. Map showing location of study reach of the West Branch Delaware River in Delhi, New York, and locations of U.S. Geological Survey streamgages...................................2

2. Map showing flood-inundation map for West Branch Delaware River, Delhi, New York, with high-water marks from the Hurricane Irene flood of August 28, 2011 .....7

\section{Tables}

1. U.S. Geological Survey streamgage information for sites on the West Branch Delaware River, Delhi, New York.

2. Simulated water-surface profiles, with corresponding estimated discharges, used in the HEC-RAS model for the West Branch Delaware River, Delhi, New York

3. Occurrence of roadway flooding at selected stages of the West Branch Delaware River, Delhi, New York. 


\section{Sheets}

[Separate documents available online with this report at the U.S. Geological Survey Publications Warehouse (http://pubs.usgs.gov/sim/3216/)]

1. Flood-inundation maps for the West Branch Delaware River, Delhi, New York, referenced to the U.S. Geological Survey streamgage, West Branch Delaware River upstream from Delhi (station number 01421900), and corresponding to a stream stage of 7.0 feet

2. Flood-inundation maps for the West Branch Delaware River, Delhi, New York, referenced to the U.S. Geological Survey streamgage, West Branch Delaware River upstream from Delhi (station number 01421900), and corresponding to a stream stage of 8.0 feet

3. Flood-inundation maps for the West Branch Delaware River, Delhi, New York, referenced to the U.S. Geological Survey streamgage, West Branch Delaware River upstream from Delhi (station number 01421900), and corresponding to a stream stage of 9.0 feet

4. Flood-inundation maps for the West Branch Delaware River, Delhi, New York, referenced to the U.S. Geological Survey streamgage, West Branch Delaware River upstream from Delhi (station number 01421900), and corresponding to a stream stage of 10.0 feet

5. Flood-inundation maps for the West Branch Delaware River, Delhi, New York, referenced to the U.S. Geological Survey streamgage, West Branch Delaware River upstream from Delhi (station number 01421900), and corresponding to a stream stage of 11.0 feet

6. Flood-inundation maps for the West Branch Delaware River, Delhi, New York, referenced to the U.S. Geological Survey streamgage, West Branch Delaware River upstream from Delhi (station number 01421900), and corresponding to a stream stage of 12.0 feet

7. Flood-inundation maps for the West Branch Delaware River, Delhi, New York, referenced to the U.S. Geological Survey streamgage, West Branch Delaware River upstream from Delhi (station number 01421900), and corresponding to a stream stage of 13.0 feet

8. Flood-inundation maps for the West Branch Delaware River, Delhi, New York, referenced to the U.S. Geological Survey streamgage, West Branch Delaware River upstream from Delhi (station number 01421900), and corresponding to a stream stage of 14.0 feet

9. Flood-inundation maps for the West Branch Delaware River, Delhi, New York, referenced to the U.S. Geological Survey streamgage, West Branch Delaware River upstream from Delhi (station number 01421900), and corresponding to a stream stage of 15.0 feet

10. Flood-inundation maps for the West Branch Delaware River, Delhi, New York, referenced to the U.S. Geological Survey streamgage, West Branch Delaware River upstream from Delhi (station number 01421900), and corresponding to a stream stage of 16.0 feet 


\section{Conversion Factors and Datums}

Inch/Pound to SI

\begin{tabular}{lcl}
\hline \multicolumn{1}{c}{ Multiply } & By & \multicolumn{1}{c}{ To obtain } \\
\hline & Length & \\
foot $(\mathrm{ft})$ & 30.48 & centimeter $(\mathrm{cm})$ \\
foot $(\mathrm{ft})$ & 0.3048 & meter $(\mathrm{m})$ \\
mile $(\mathrm{mi})$ & 1.609 & kilometer $(\mathrm{km})$ \\
\hline & Area & \\
\hline square foot $\left(\mathrm{ft}^{2}\right)$ & 0.09290 & square meter $\left(\mathrm{m}^{2}\right)$ \\
square mile $\left(\mathrm{mi}^{2}\right)$ & 2.590 & square kilometer $\left(\mathrm{km}^{2}\right)$ \\
\hline & Flow rate & \\
\hline cubic foot per second $\left(\mathrm{ft}^{3} / \mathrm{s}\right)$ & 0.02832 & cubic meter per second $\left(\mathrm{m}^{3} / \mathrm{s}\right)$ \\
\hline
\end{tabular}

Vertical coordinate information is referenced to either (1) stage, the height above an arbitrary datum established at a streamgage, or (2) elevation, the height above the North American Vertical Datum of 1988 (NAVD 88).

Horizontal coordinate information is referenced to the North American Datum of 1983 (NAD 83). 


\title{
Flood-Inundation Maps for the West Branch Delaware River, Delhi, New York, 2012
}

\author{
By William F. Coon and Brian K. Breaker
}

\section{Abstract}

Digital flood-inundation maps for a 5-mile reach of the West Branch Delaware River through the Village and part of the Town of Delhi, New York, were created by the U.S. Geological Survey (USGS) in cooperation with the Village of Delhi, the Delaware County Soil and Water Conservation District, and the Delaware County Planning Department. The inundation maps, which can be accessed through the USGS Flood Inundation Mapping Science Web site at http:// water.usgs.gov/osw/flood_inundation/ and the Federal Flood Inundation Mapper Web site at http://wim.usgs.gov/FIMI/ FloodInundationMapper.html, depict estimates of the areal extent and depth of flooding corresponding to selected water levels (stages) referenced to the USGS streamgage at West Branch Delaware River upstream from Delhi, N.Y. (station number 01421900).

In this study, flood profiles were computed for the stream reach by means of a one-dimensional step-backwater model that had been used to produce the flood insurance rate maps for the most recent flood insurance study for the Town and Village of Delhi. This hydraulic model was used to compute 10 water-surface profiles for flood stages at 1-foot (ft) intervals referenced to the streamgage datum and ranging from $7 \mathrm{ft}$ or near bankfull to $16 \mathrm{ft}$, which exceeds the stages that correspond to both the estimated 0.2-percent annual-exceedanceprobability flood (500-year recurrence interval flood) and the maximum recorded peak flow. The simulated water-surface profiles were then combined with a geographic information system (GIS) digital elevation model, which was derived from Light Detection and Ranging (LiDAR) data with a 1.2-ft (0.61-ft root mean squared error) vertical accuracy and $3.3-\mathrm{ft}$ (1-meter) horizontal resolution, to delineate the area flooded at each water level. A map that was produced using this method to delineate the inundated area for the flood that occurred on August 28, 2011, agreed well with highwater marks that had been located in the field using a global positioning system. The availability of the 10 flood-inundation maps on the USGS Flood Inundation Mapping Science Web site, along with Internet information regarding current stage from the USGS streamgage, will provide emergency management personnel and residents with information that is critical for floodresponse activities, such as evacuations and road closures, as well as for post-flood recovery efforts.

\section{Introduction}

The Village of Delhi is a small rural community in the Town of Delhi, Delaware County, New York (fig. 1), with a population of 3,087 (Richard Maxey, Mayor, Village of Delhi, N.Y., oral commun., 2012). Delhi has experienced severe flooding numerous times along the West Branch Delaware River, most notably during January 1996, June 2006, October 2010, and August 2011. Most of the flood plain in the village on the northwestern side of the West Branch Delaware River is used for residential and commercial purposes; therefore, when flooding occurs, the damages and costs can be great.

Prior to this study, emergency responders in Delhi have relied on several information sources (all of which are available on the Internet) to make decisions on how to best alert the public and minimize the dangers associated with flooding. One source is the Federal Emergency Management Agency (FEMA) Flood Insurance Study (FIS) for the Town and Village of Delhi dated August 1, 2009 (Federal Emergency Management Agency, 2009a and 2009b). A second source of information is the U.S. Geological Survey (USGS) streamgage, West Branch Delaware River upstream from Delhi, N.Y. (station number 01421900; table 1), from which current (U.S. Geological Survey, 2011a) and recent (U.S. Geological Survey, 2011b) water levels and discharges (starting in December 1996) can be obtained. A discontinued USGS streamgage (01422000) that was located within the village limits and 0.9 mile downstream from the current streamgage provided water-level (stage) data from 1937 to 1970. The streamflow record from this earlier streamgage is considered equivalent to the record collected at the current streamgage. Station 01422000 is shown in the figures in this report for informational purposes only. The combined peak-flow data from both stations are available through the USGS National Water Information System (U.S. Geological Survey, 2011b). A third source of flood-related information is the National 


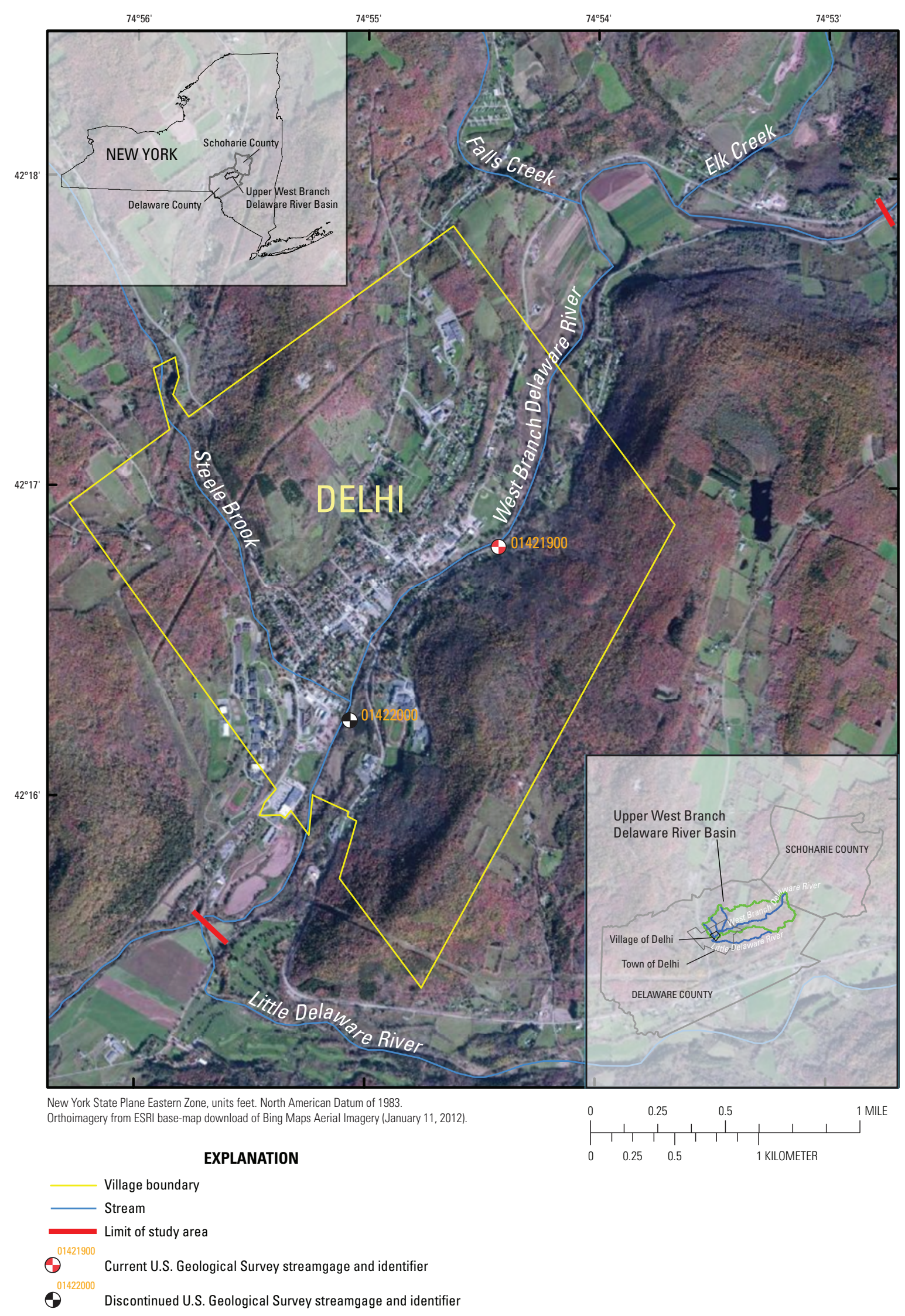

Figure 1. Location of study reach of the West Branch Delaware River in Delhi, New York, and locations of U.S. Geological Survey streamgages. 
Table 1. U.S. Geological Survey streamgage information for sites on the West Branch Delaware River, Delhi, New York.

[Station locations are shown in figure 1. ft, feet; ft³/s, cubic feet per second; NAVD 88, North American Vertical Datum of 1988]

\begin{tabular}{|c|c|c|}
\hline & \multicolumn{2}{|c|}{ Station name } \\
\hline & $\begin{array}{c}\text { West Branch Delaware River } \\
\text { at Delhi }\end{array}$ & $\begin{array}{c}\text { West Branch Delaware River } \\
\text { upstream from Delhi }\end{array}$ \\
\hline Station number & 01422000 & 01421900 \\
\hline Drainage area (square miles) & 142 & 134 \\
\hline Latitude & $42^{\circ} 16^{\prime} 16^{\prime \prime}$ & $42^{\circ} 16^{\prime} 49^{\prime \prime}$ \\
\hline Longitude & $74^{\circ} 55^{\prime} 05^{\prime \prime}$ & $74^{\circ} 54^{\prime} 27^{\prime \prime}$ \\
\hline $\begin{array}{l}\text { Period of peak-flow record } \\
\quad\left(\text { water years }^{1}\right)\end{array}$ & $1937-74,1996$ & $1997-2011$ \\
\hline $\begin{array}{l}\text { Maximum recorded stage, in } \mathrm{ft} \text {, gage datum } \\
\text { (elevation, in } \mathrm{ft} \text { above NAVD } 88 \text { ) and date }\end{array}$ & $\begin{array}{c}9.8(1,354.6) \\
\text { January } 19,1996\end{array}$ & $\begin{array}{l}12.53(1,363.55) \\
\text { August } 28,2011\end{array}$ \\
\hline Maximum discharge, in $\mathrm{ft}^{3} / \mathrm{s}$, and date & $\begin{array}{c}{ }^{2} 13,000 \\
\text { January } 19,1996\end{array}$ & $\begin{array}{c}8,860 \\
\text { August 28, } 2011\end{array}$ \\
\hline
\end{tabular}

\footnotetext{
${ }^{1}$ Water year is the 12-month period from October 1 of one year through September 30 of the following year and is designated by the calendar year in which it ends.

${ }^{2}$ Estimated.
}

Weather Service (NWS) Advanced Hydrologic Prediction Service (AHPS), which also displays the USGS stage data from the Delhi streamgage (National Weather Service, 2011). The NWS forecasts flood stages at many USGS streamgages but does not do so for headwater streamgages with relatively small drainage areas, such as West Branch Delaware River upstream from Delhi, because the time between a precipitation runoff event and peak streamflow at a streamgage is shorter than the 6-hour time step used by the NWS for stage forecasts.

Although the current stage at a USGS streamgage is particularly useful for residents in the immediate vicinity of a streamgage, it is of limited use to residents farther upstream or downstream because the water-surface elevation is not constant along the entire stream reach. Knowledge of a stage at a streamgage is difficult to translate into water levels - both their depth and aerial extent - at different locations along a stream. One way to address these informational gaps is to produce a library of flood-inundation maps that are referenced to the stages recorded at the USGS streamgage. By referring to the appropriate map, emergency responders can discern the severity of flooding (depth of water and aerial extent), identify roads that are or soon will be flooded, and make plans for notification or evacuation of residents in harm's way for some distance upstream and downstream from the streamgage. In addition, the capability to visualize the potential extent of flooding has been shown to motivate residents to take precautions and heed warnings that they previously might have disregarded; therefore, in 2011, the USGS, in cooperation with the Village of Delhi, N.Y.; the Delaware County Soil and Water Conservation District; and the Delaware County Planning Department, conducted a study to produce a library of flood-inundation maps for the West Branch Delaware River near Delhi, N.Y.

\section{Purpose and Scope}

The purpose of this report is to describe the development of a series of flood-inundation maps for the West Branch Delaware River near Delhi, N.Y., and to present the maps, which are also available on the USGS Flood Inundation Mapping Science Web site (U.S. Geological Survey, 2012c). The floodinundation maps cover a reach about 5 miles (mi) long from about 2 mi upstream from the village's northeastern boundary near the confluence of West Branch Delaware River and Elk Creek to about $0.5 \mathrm{mi}$ downstream from the village's southwestern boundary at the confluence of West Branch Delaware River and Little Delaware River (fig. 1). The maps were produced for flood levels, referenced to the stage recorded at the USGS streamgage on the West Branch Delaware River upstream from Delhi (01421900), that range from 7 feet (ft), 
gage datum, or approximately bankfull, to $16 \mathrm{ft}$, gage datum, or greater than the stage associated with the estimated 0.2-percent annual-exceedance-probability flood (500-year recurrence interval flood) and the maximum recorded peak flow.

\section{Study Area Description}

The West Branch Delaware River is in the Catskill Mountain region of southeastern New York. Although the river starts in Schoharie County, most of the basin is in Delaware County, through which the river flows in a southwestwardly direction. At the USGS streamgage upstream from the Village of Delhi (01421900), the drainage area is 134 square miles. About 74 percent of the basin at this point is forested (U.S. Geological Survey, 2012a); most of the remaining basin is in agricultural and rural-developed land uses. The basin terrain is generally steep. The average basin slope is 0.17 , and the main-channel slope is 0.004 (U.S. Geological Survey, 2012a). The mean annual precipitation is 43.2 inches (in.) (National Oceanic and Atmospheric Administration, 2012); the mean annual runoff is 24.5 in. (U.S. Geological Survey, 2012b). The study reach is approximately $5 \mathrm{mi}$ long, has an average top-ofbank channel width of about 100 to $150 \mathrm{ft}$, and has an average channel slope of 0.0017 . Three major tributaries connect with the West Branch Delaware River in the vicinity of Delhi. Elk Creek and Falls Creek meet the river about 1 mi upstream from the village, whereas Steele Brook joins the river within the village limits. Two bridges cross the main channel within the village limits at Bridge Street and N.Y. Route 28 (Kingston Street). A third bridge at Sherwood Road is located at the downstream end of the study reach and just upstream from the confluence of the West Branch Delaware River with Little Delaware River.

\section{Previous Studies}

FEMA flood insurance studies for both the Village and Town of Delhi were conducted by Leonard Jackson Associates in 1985 (Federal Emergency Management Agency, 1985a and b). These FISs were updated and included in a countywide study that was completed by URS Corporation, in association with Dewberry and Davis, LLC, in 2009 (Federal Emergency Management Agency, 2009a and b). The 2009 FIS covers West Branch Delaware River from about 5.5 mi upstream from the Village of Delhi to the confluence of the West Branch with East Branch Delaware River almost $60 \mathrm{mi}$ downstream. The hydrologic and hydraulic analyses were performed by URS Corporation. The flood-inundation areas for all detailed study reaches were produced by Dewberry and Davis, LLC, and were delineated using high-resolution topographic data that were generated from LiDAR (Light Detection and Ranging) data (Federal Emergency Management Agency, 2009a). The LiDAR data were collected during 2007 and were used to more precisely delineate flood plains in the detailed study areas than was previously possible.

\section{Approach}

The USGS has standardized procedures for creating flood-inundation maps for flood-prone communities (U.S. Geological Survey, 2012c) so that the process followed and products produced are similar regardless of which USGS office is responsible for the work. Tasks specific to development of the flood maps for Delhi, N.Y., included (1) attainment of the hydraulic model that was used for the most recent FEMA flood insurance study (Federal Emergency Management Agency, 2009a and 2009b); (2) computation of watersurface profiles and production of estimated flood-inundation maps for various stream stages using the U.S. Army Corps of Engineer's River Analysis System (HEC-RAS) computer program and mapping utility, RAS Mapper (U.S. Army Corps of Engineers, 2010); (3) collection of highwater elevations during the flood of August 28, 2011, to verify the estimated flood-inundation maps; and (4) preparation of the maps for display on the USGS Flood Inundation Mapping Science Web site (U.S. Geological Survey, 2011c).

\section{Computation of Water-Surface Profiles}

The water-surface profiles used to produce the 10 floodinundation maps in this study were computed using HECRAS, version 4.1.0 (U.S. Army Corps of Engineers, 2010). HEC-RAS is a one-dimensional step-backwater model for simulation of water-surface profiles with steady-state (gradually varied) or unsteady-state flow computation options. The HEC-RAS model that was used for the 2009 FIS was used essentially "as-is" for production of flood maps so as to ensure agreement between published FIS flood maps and those produced by the current study. The HEC-RAS model was obtained from Dewberry and Davis, LLC (Dewberry and Davis, LLC, written commun., April 2011). Minor revisions made to the model are described in the following sections.

\section{Topographic Data}

Channel cross sections and bridge geometry data were obtained from the HEC-RAS model that was used for the 2009 FIS. Data for seven cross sections - one at the current streamgage location and six at the upstream end of the study reach-were added to the model. Within the study reach, no structures have been modified or new structures added since the completion of the FIS (Federal Emergency Management Agency, 2009a and b).

LiDAR data with horizontal resolution of $3.3 \mathrm{ft}$ (1 meter) and vertical accuracy of $1.2 \mathrm{ft}(0.61 \mathrm{ft}$ or 18.5 centimeters root mean squared error) were used to extract elevation data for the new cross sections. The LiDAR data were collected for the New York City Department of Environmental Protection as part of the New York State Digital Orthoimagery Program through the New York State Office of Cyber Security and Critical Infrastructure Coordination (2009). The LiDAR data were 
collected during April to June 2009, and were postprocessed by the Sanborn Map Company, Colorado Springs, Colorado. The data, which were acquired from New York State Department of Environmental Conservation, were clipped to the area required to produce the flood-inundation maps for the West Branch Delaware River near Delhi. Elevations of the LiDAR data are referenced to the North American Vertical Datum of 1988 (NAVD 88).

HEC-GeoRAS (U.S. Army Corps of Engineers, 2009), a set of procedures, tools, and utilities for processing geospatial data in ArcGIS by using a graphical user interface, was used to extract digital elevation data from the LiDAR dataset for the seven new cross sections. These geometric data were subsequently imported into HEC-RAS. Because the LiDAR data could not provide the same level of detail for the submerged parts of the cross sections as is possible with surveyed data, the streambed elevations of the imported data were adjusted on the basis of bed elevations of the FIS cross sections proximal to the new cross sections and on the bed slope of the channel.

\section{Hydrologic and Steady-State Flow Data}

The study reach includes one streamgage (01421900; fig. 1; table 1) that has been in operation at the current site since December 1996. Stage is measured every 15 minutes, is transmitted hourly by a satellite radio in the streamgage, and is made available on the Internet through the USGS National Water Information System (U.S. Geological Survey, 2011a). Stage data from this streamgage are referenced to a local datum but can be converted to water-surface elevations referenced to the NAVD 88 by adding $1,350.82 \mathrm{ft}$.

The HEC-RAS analysis for this study was done using the steady-state flow computation option. Steady-state flow data consist of the flow regime, boundary conditions (normal depth), and peak flows that produced water-surface elevations at the streamgage cross section, which matched target watersurface elevations. These target elevations coincided with even foot increments of stage, referenced to the local gage datum. The FIS model simulated the addition of flows downstream from Steele Brook about mid-way through the village. To ensure that the profiles developed as part of the current study would agree with those from the FIS, the increases in flows downstream from Steele Brook for these new profiles were extrapolated or interpolated from the FIS flows.

\section{Model Calibration and Performance}

The 2009 HEC-RAS model was used with no other changes than the addition of the seven cross sections as described previously. The roughness coefficients used for the six upstream cross sections were comparable to those used for other cross sections in the model. The roughness coefficients for the cross section at the streamgage were adjusted to minimize the differences between simulated water-surface elevations and those estimated from profile plots for the 10-, 2-, 1-, and 0.2-percent annual-exceedance-probability floods that were presented in the FIS. The greatest discrepancy in water-surface elevations for these four simulations was $0.16 \mathrm{ft}$. For the 10 water-surface profiles that were created for this study, steady-flow discharges in the model were adjusted to produce the desired water-surface elevations at the streamgage.

Discharges in the original HEC-RAS model were increased downstream from the confluence with Steele Brook at the site of the discontinued USGS streamgage (01422000). These increases presumably were intended to account for and maintain tributary inflows at flood-frequency magnitudes that were comparable to those being simulated in the main channel. Therefore, proportional increases in discharges (table 2) for the 10 simulations performed for the current study were selected with the assumption that the percentage of increase in discharge for any given simulation was the same as that for the 2009 FIS.

Table 2. Simulated water-surface profiles, with corresponding estimated discharges, used in the HEC-RAS model for the West Branch Delaware River, Delhi, New York.

[NAVD 88, North American Vertical Datum of 1988; ft, feet; $\mathrm{ft}^{3} / \mathrm{s}$, cubic feet per second. Water-surface profiles include ten 1-foot increments of stage, referenced to the U.S. Geological Survey streamgage upstream from Delhi, and four annual exceedence probability floods (AEPF) from the most recent flood insurance study (Federal Emergency Management Agency, 2009a). Bold values are from the original HEC-RAS model developed for the most recent flood insurance study (Federal Emergency Management Agency, 2009a)]

\begin{tabular}{|c|c|c|c|}
\hline $\begin{array}{c}\text { Water-surface } \\
\text { profile }\end{array}$ & $\begin{array}{c}\text { Target } \\
\text { water-surface } \\
\text { elevation, } \\
\text { in feet, } \\
\text { NAVD } 88\end{array}$ & $\begin{array}{c}\text { Estimated } \\
\text { discharge at } \\
\text { upstream end } \\
\text { of study reach } \\
\left(\mathrm{ft}^{3} / \mathrm{s}\right)\end{array}$ & $\begin{array}{c}\text { Estimated } \\
\text { discharge } \\
\text { downstream from } \\
\text { confluence with } \\
\text { Steele Brook } \\
\left(\mathrm{ft}^{3} / \mathrm{s}\right)\end{array}$ \\
\hline Stage $7 \mathrm{ft}$ & $1,357.82$ & 1,915 & 3,008 \\
\hline Stage $8 \mathrm{ft}$ & $1,358.82$ & 2,625 & 4,123 \\
\hline Stage $9 \mathrm{ft}$ & $1,359.82$ & 3,490 & 5,482 \\
\hline Stage $10 \mathrm{ft}$ & $1,360.82$ & 4,460 & 7,006 \\
\hline Stage $11 \mathrm{ft}$ & $1,361.82$ & 5,600 & 8,797 \\
\hline 10-percent AEPF & ${ }^{1} 1,362.3$ & 6,399 & 9,986 \\
\hline Stage $12 \mathrm{ft}$ & $1,362.82$ & 6,940 & 10,901 \\
\hline Stage $13 \mathrm{ft}$ & $1,363.82$ & 8,575 & 13,470 \\
\hline 2-percent AEPF & ${ }^{1} 1,364.1$ & 8,828 & 13,892 \\
\hline 1-percent AEPF & ${ }^{1} 1,364.6$ & 9,883 & 15,559 \\
\hline Stage $14 \mathrm{ft}$ & $1,364.82$ & 10,160 & 15,960 \\
\hline Stage $15 \mathrm{ft}$ & $1,365.82$ & 12,210 & 19,180 \\
\hline 0.2 -percent AEPF & ${ }^{1} 1,365.9$ & 12,372 & 19,483 \\
\hline Stage $16 \mathrm{ft}$ & $1,366.82$ & 14,350 & 22,541 \\
\hline
\end{tabular}

${ }^{1}$ Elevation was estimated from water-surface profile plot, Plate 154P, in Federal Emergency Management Agency (2009b). 


\section{Development of Water-Surface Profiles}

Water-surface profiles were developed for a total of 10 stages at 1-ft intervals referenced to the USGS streamgage West Branch Delaware River upstream from Delhi (01421900). The profiles range in stage from $7 \mathrm{ft}$, or near bankfull, to $16 \mathrm{ft}$, gage datum $(1,357.82$ to $1,366.82 \mathrm{ft}$, NAVD 88). The maximum stage exceeds the stages that correspond to both the estimated 0.2-percent annual-exceedance-probability flood from the 2009 FIS (12,370 cubic feet per second $\left.\left(\mathrm{ft}^{3} / \mathrm{s}\right)\right)$ and the maximum recorded peak flow $\left(13,000 \mathrm{ft}^{3} / \mathrm{s}\right.$ on January 19,1996$)$. Water-surface elevations at each cross section in the HEC-RAS model were computed for each simulated profile.

\section{Development of Inundation Maps}

Flood-inundation maps were created in a geographic information system (GIS) for the 10 water-surface profiles by combining the profiles and digital elevation model (DEM) data. The DEM data were derived from the same LiDAR data that were obtained from New York State Department of Environmental Conservation and used for elevation data for the cross sections added to the HEC-RAS model.

Estimated flood-inundation boundaries for each simulated profile were developed with RAS Mapper (U.S. Army Corps of Engineers, 2010), a mapping utility that overlays geometric data and water-surface profiles from HEC-RAS onto a digital terrain layer. As with the LiDAR data from which the flood maps were derived, the resulting flood maps have a vertical accuracy of about $1.2 \mathrm{ft}$. The mapped areas of inundation are overlaid on high-resolution, geo-referenced, aerial photographs of the study area. The most up-to-date orthoimagery available (Bing Maps Services, 2011) was downloaded from an Esri basemap Web site (Esri, 2011) for this purpose. Shapefile polygons and depth grids of the inundated areas for each profile were modified, as required, in the ArcMap application of ArcGIS, version 10 (Esri, 2011), to ensure a hydraulically reasonable transition of the flood boundaries between modeled cross sections. Any inundated areas that were detached from the main channel and, therefore, erroneously delineated as parts of the flood extent were removed from the mapped inundated areas. Bridge surfaces that were shown to be overtopped by flood waters, when in fact the water level was below the bridge deck, were corrected to depict non-inundated conditions. The shapefile polygons of the inundated areas are shaded to depict variations in water depth. Actual estimates of water depth can be obtained from the depth-grid data that are included with the presentation of the flood maps on the interactive online map-library Web site described in the following section, "Flood-Inundation Maps on the Internet."

High-water marks along the main channel following the flood of August 28, 2011, that was caused by Hurricane Irene were located with a hand-held global positioning system. The peak discharge of this flood was $8,860 \mathrm{ft}^{3} / \mathrm{s}$ at a recorded stage of $12.53 \mathrm{ft}$, gage datum $(1,363.35 \mathrm{ft}$, NAVD 88$)$. The highwater marks, which identified the edge of the inundated area along the northwestern bank of the West Branch Delaware River, were superimposed on an inundation map that was created for this flood following the same procedures described above (fig. 2). The field-surveyed flood boundary closely matched the areal extent of the GIS-generated flood-inundation map produced by HEC-RAS and RAS Mapper.

The 10 flood maps at 1-ft increments of stage that were produced for West Branch Delaware River near Delhi are not included in this report. Rather they are available on the Internet, as described in the following section. Examination of the 10 flood maps permits assessment of changes in the extents of flooding as the water level of the West Branch Delaware River increases. A critical stage value can be associated with specific areas of the village that are susceptible to flooding. For example, knowledge of the stages at which certain roadway or bridge flooding will occur (table 3) would be beneficial to emergency responders. Areas that are prone to flooding, but only during extreme events, can also be identified. Residents in these areas might be more at risk from the dangers of flooding simply because they lack the periodic exposure to floods that residents in other areas regularly experience.

Table 3. Occurrence of roadway flooding at selected stages of the West Branch Delaware River, Delhi, New York.

[Stage is referenced to the water level measured at the U.S. Geological Survey streamgage, West Branch Delaware River upstream from Delhi (01421900)]

Stage,
in feet

10 Bridge Street flooding on right bank begins.

11 Bridge Street on right bank is inundated.

12 Sherwood Road flooding on left bank begins.

13 Bridge Street bridge is inundated. Sherwood Road on left bank is inundated.

14 Kingston Street (Route 28) bridge is inundated. Kingston Street flooding on right bank begins.

Kingston Street on right bank is inundated. Main Street (Route 10) is flooded between Court Street and Division Street.

Sherwood Road bridge is inundated.

16 Main Street (Route 10) is flooded northeast of Bridge Street. 


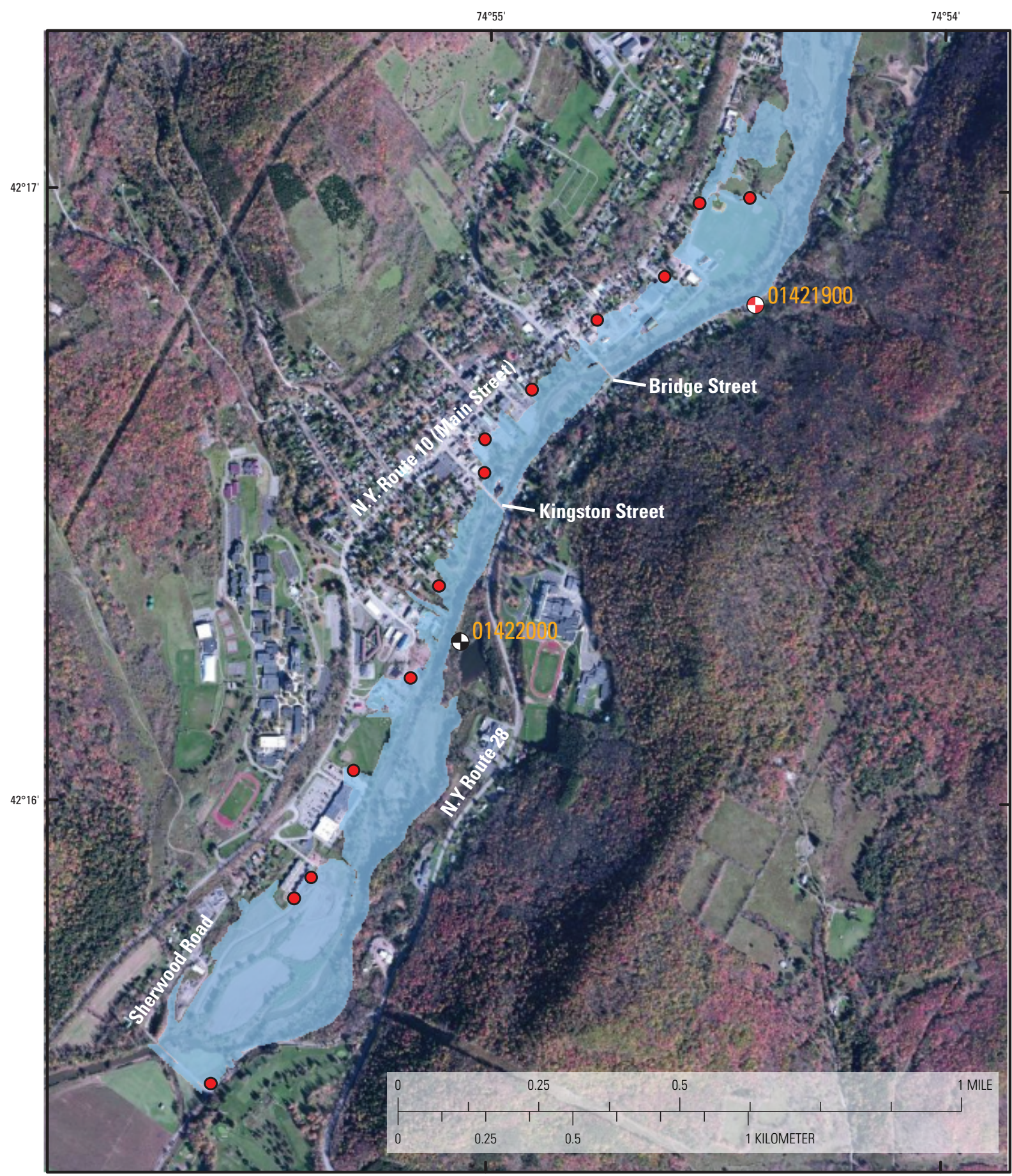

New York State Plane Eastern Zone, units feet. North American Datum of 1983

Orthoimagery from ESRI base-map download of Bing Maps Aerial Imagery (January 11, 2012).

EXPLANATION

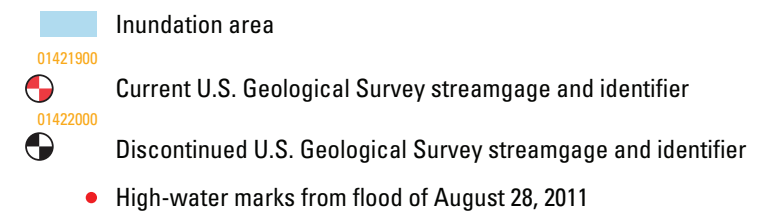

Figure 2. Flood-inundation map for West Branch Delaware River, Delhi, New York, with high-water marks from the Hurricane Irene flood of August 28, 2011. (Stage of 12.53 feet, gage datum, and 1,363.35 feet, North American Vertical Datum 1988, referenced to the U.S. Geological Survey streamgage 01421900) 


\section{Flood-Inundation Maps on the Internet}

The flood-inundation maps and current study documentation are available online at the U.S. Geological Survey Publications Warehouse (http://pubs.usgs.gov/sim/3216/). Also, a Flood Inundation Mapping Science Web site (U.S. Geological Survey, 2011c) has been established to provide a portal at http://water.usgs.gov/osw/flood_inundation/ to make USGS flood-inundation study information available to the public. That Web portal has a link (http://wim.usgs.gov/ FIMI/FloodInundationMapper.html) to interactive online map libraries that can be downloaded in several commonly used electronic file formats. Included on this latter Web site is a link to the USGS National Water Information System (U.S. Geological Survey, 2011a), which presents graphs of the current stage and streamflow at the USGS streamgage 01421900 to which the inundation maps are referenced. A link also is provided to the NWS Advanced Hydrologic Prediction Service (AHPS) site (National Weather Service, 2011); however, because the NWS does not forecast stage at this site, the data presented on the USGS and NWS Web sites are identical. The estimated flood-inundation maps are displayed in sufficient detail to note the extent of flooding with respect to individual structures so that preparations for flooding and decisions for emergency response can be performed in a timely and efficient manner. Roadways and bridges were closely reviewed and are shown as shaded (inundated and likely impassable) or not shaded (dry and passable) to facilitate emergency planning and response. However, buildings that are shaded do not reflect inundation but denote that bare earth surfaces in the vicinity of the buildings are inundated. When the water depth (as indicated in the Web Mapping Application at http://wim.usgs.gov/ FIMI/FloodInundationMapper.html by holding the cursor over an inundated area) in the vicinity of the building of interest exceeds that building's height, the structure can be considered fully submerged.

\section{Disclaimer for Flood-Inundation Maps}

Inundated areas shown on the flood maps should not be used for navigation, regulatory, permitting, or other legal purposes. The USGS provides these maps "as-is" for a quick reference, emergency planning tool but assumes no legal liability or responsibility resulting from the use of this information.

\section{Uncertainty Associated with Inundation Maps}

Although the flood-inundation maps represent the boundaries of inundated areas with a distinct line, some uncertainty is associated with these maps. The flood boundaries shown were estimated on the basis of stages at the USGS streamgage upstream from Delhi (01421900). Water-surface elevations along the stream reaches were estimated by steadystate hydraulic modeling, assuming unobstructed flow, and using streamflows and hydrologic conditions anticipated at the USGS streamgage. The hydraulic model reflects the land-cover characteristics and any bridge or other hydraulic structures existing as of March 2012. Unique meteorological factors (timing and distribution of precipitation) may cause actual streamflows along the modeled reach to vary from those assumed during a flood, which may lead to deviations in the water-surface elevations and inundation boundaries shown. Additional areas may be flooded as a result of unanticipated conditions, such as changes in the streambed elevation or roughness, backwater into major tributaries along a main stem river, or backwater from localized debris or ice jams. The accuracy of the floodwater extent portrayed on these maps will vary with the accuracy of the digital elevation model used to simulate the land surface.

If this series of flood-inundation maps will be used in conjunction with National Weather Service (NWS) river forecasts, the user should be aware of additional uncertainties that may be inherent or factored into NWS forecast procedures. The NWS uses forecast models to estimate the quantity and timing of water flowing through selected stream reaches in the United States. These forecast models (1) estimate the amount of runoff generated by precipitation and snowmelt, (2) simulate the movement of floodwater as it proceeds downstream, and (3) predict the flow and stage (water-surface elevation) for the stream at a given location (AHPS forecast point) throughout the forecast period (every 6 hours and 3 to 5 days out in many locations). For more information on AHPS forecasts, please see: http://water.weather.gov/ahps/pcpn_and_river_ forecasting.pdf.

\section{Summary}

A series of 10 digital flood-inundation maps were developed, in cooperation with the Village of Delhi, New York; the Delaware County Soil and Water Conservation District; and the Delaware County Planning Department, for the West Branch Delaware River near Delhi. The maps cover a reach about 5 miles (mi) long from about 2 mi upstream from the village's northeastern boundary near the confluence of West Branch Delaware River and Elk Creek to about 0.5 mi downstream from the village's southwestern boundary at the confluence of West Branch Delaware River and Little Delaware River. An existing hydraulic model, developed using the U.S. Army Corps of Engineers' HEC-RAS program and used to create flood-inundation maps for the most recent (2009) flood insurance studies for the Village and Town of Delhi, was used to compute water-surface profiles for the study reach. Ten water-surface profiles for flood stages at 1-foot (ft) intervals, referenced to the streamgage datum and ranging from $7 \mathrm{ft}$, or near bankfull, to $16 \mathrm{ft}$, gage datum $(1,357.82$ to $1,366.82 \mathrm{ft}$, NAVD 88), were created. The maximum stage exceeds the stages that correspond to both the estimated 0.2-percent annualexceedance-probability flood and the maximum recorded peak flow. The simulated water-surface profiles were then combined with a geographic information system (GIS) digital elevation model (derived from Light Detection and Ranging (LiDAR) data) and RAS Mapper, a mapping utility included in 
HEC-RAS, to delineate estimated flood-inundation areas as shapefile polygons and depth grids for each profile. A map that was produced by this method to delineate the inundated area for the flood that occurred on August 28, 2011, agreed well with highwater marks that had been located in the field using a global positioning system. These maps were overlaid on highresolution, georeferenced, aerial photographs of the study area and were shaded to give a general indication of depth of water at any point. The maps were modified, as required, to remove any inundated areas that were detached from the main channel and were erroneously delineated as part of the flood extent and to correctly depict inundation of bridge surfaces.

Current conditions at the USGS streamgage (01421900) can be obtained on the Internet through the USGS National Water Information System (http://waterdata.usgs.gov/nwis/) or the National Weather Service (NWS) Advanced Hydrologic Prediction Service (AHPS; http://water.weather.gov/ahps/). The NWS forecasts flood stages for many places that are collocated with USGS streamgages, but because of the relatively small drainage area of the West Branch Delaware River at Delhi and the short time between peak rainfall and peak streamflow at Delhi, the NWS does not forecast flood stages for this site. The flood maps, available at the USGS Flood Inundation Mapping Science Web site, in conjunction with the real-time stage data from the USGS streamgage, will help to guide the general public in taking individual safety precautions and will provide emergency management personnel with a tool to efficiently manage emergency flood operations and post-flood recovery efforts.

\section{References Cited}

Bing Maps Services, 2011, Bing Maps Aerial Imagery: ArcGIS Online web mapping service, accessed November 22, 2011, at http://www.esri.com/software/arcgis/arcgisonline/ bing-maps.html.

Esri, 2011, ArcGIS 10, accessed November 22, 2011, at http:// www.esri.com/software/arcgis/arcgis10/index.html.

Federal Emergency Management Agency, 1985a, Flood Insurance Study, Town of Delhi, Delaware County, New York, July 18, 1985: Washington, D.C., Federal Emergency Management Agency, 26 p.

Federal Emergency Management Agency, 1985b, Flood Insurance Study, Village of Delhi, Delaware County, New York, July 18, 1985: Washington, D.C., Federal Emergency Management Agency, 21 p.

Federal Emergency Management Agency, 2009a, Flood insurance study, Delaware County, New York (all jurisdictions), Volume 1: Federal Emergency Management Agency, 140 p., accessed November 15, 2011, at http://www.ramppteam. com/county_maps/new_york/delaware/delaware_ny_fis_ tables1.pdf.
Federal Emergency Management Agency, 2009b, Flood insurance study, Delaware County, New York (all jurisdictions), Volume 2: Federal Emergency Management Agency, 110 p., accessed November 15, 2011, at http://www.ramppteam. com/county_maps/new_york/delaware/delaware_ny_fis_ tables2.pdf.

National Oceanic and Atmospheric Administration, 2012, National Climatic Data Center: National Oceanic and Atmospheric Administration, Satellite and Information Service, accessed February 1, 2012, at http://www.ncdc.noaa.gov/oa/ ncdc.html.

National Weather Service, 2011, Advanced Hydrologic Prediction Service, accessed December 16, 2011, at http://water. weather.gov/ahps2/index.php?wfo=bgm.

New York State Office of Cyber Security and Critical Infrastructure Coordination, 2009, 2009 LiDAR metadata for the NYCDEP (New York City Department of Environmental Protection) project area: New York State Digital Orthoimagery Program, Albany, N.Y.

U.S. Army Corps of Engineers, Hydrologic Engineering Center, 2009, HEC-GeoRAS, GIS Tools for Support of HECRAS using ArcGIS, User's Manual, version 4.2: U.S. Army Corps of Engineers, [variously paged].

U.S. Army Corps of Engineers, Hydrologic Engineering Center, 2010, HEC-RAS River Analysis System, Hydraulic Reference Manual, version 4.1: U.S. Army Corps of Engineers, [variously paged].

U.S. Geological Survey, 2011a, USGS 01421900 West Branch Delaware River upstream from Delhi, N.Y.: U.S. Geological Survey, accessed December 16, 2011, at http://waterdata. usgs.gov/ny/nwis/uv?site_no $=01421900$.

U.S. Geological Survey, 2011b, USGS Surface-water data for the Nation: U.S. Geological Survey, accessed December 16, 2011, at http://waterdata.usgs.gov/nwis/sw.

U.S. Geological Survey, 2011c, Federal flood inundation mapper: U.S. Geological Survey, accessed December 16, 2011, at http://wim.usgs.gov/FIMI/FloodInundationMapper.html.

U.S. Geological Survey, 2012a, New York StreamStats: U.S. Geological Survey, accessed January 12, 2012, at http:// streamstatsags.cr.usgs.gov/ny_ss/default.aspx?stabbr=ny\&d $\mathrm{t}=12737674080151$.

U.S. Geological Survey, 2012b, Water-resources data for the United States, water year 2010: U.S. Geological Survey, accessed February 1, 2012, at http://wdr.water.usgs.gov/ wy2010/pdfs/01421900.2010.pdf.

U.S. Geological Survey, 2012c, USGS Flood Inundation Mapping Science: U.S. Geological Survey, accessed February 3, 2012, at http://water.usgs.gov/osw/flood_inundation/ toolbox/. 

For more information, contact:

Director

U.S. Geological Survey

New York Water Science Center

425 Jordan Road

Troy, NY 12180-8349

or visit our Web site at:

http://ny.water.usgs.gov/

Document prepared by the West Trenton Publishing Service Center 
通 